\section{Mammalian sperm translate nuclear-encoded proteins by mitochondrial-type ribosomes}

\author{
Yael Gur and Haim Breitbart ${ }^{1}$ \\ Faculty of Life Sciences, Bar-Ilan University, Ramat-Gan \\ 52900, Israel
}

It is widely accepted that spermatozoa are translationally silent. The present study demonstrates, for the first time, incorporation of labeled amino acids into polypeptides during sperm capacitation, which was completely inhibited by mitochondrial translation inhibitors but not by the cytoplasmic translation inhibitor. Unlike 80S cytoplasmic ribosomes, $55 \mathrm{~S}$ mitochondrial ribosomes were present in polysomal fractions, indicating that these ribosomes are actively involved in protein translation in spermatozoa. Inhibition of protein translation significantly reduced sperm motility, capacitation and in vitro fertilization rate. Thus, contrary to the accepted dogma, nuclear genes are expressed as proteins in sperm during their residence in the female reproductive tract until fertilization.

Supplemental material is available at http://genesdev.org.

Received September 20, 2005; revised version accepted December 19, 2005.

It is generally accepted that nuclear-encoded protein translation is unlikely to occur in mature sperm cells. However, indications to the contrary include the findings that mammalian spermatozoa contain nuclear-encoded mRNAs (Wykes et al. 1997; Miller et al. 1999; Ostermeier et al. 2002) in addition to their ability to synthesize mitochondrial-encoded RNA (Premkumar and Bhargava 1972; Hecht and Williams 1978; Alcivar et al. 1989) and proteins (Premkumar and Bhargava 1972; Bragg and Handel 1979). It is interesting that those papers, in spite of being published in respectable journals, did not disprove the generally accepted axiom that spermatozoa are translationally and transcriptionally incapable. In the 1970s it was believed that there was no physiological need for protein replacement before fertilization.

Mammalian spermatozoa reside in the female genital tract for several hours between ejaculation and fertilization, first as sperm reservoir (Suarez 2002) and later on for capacitation. Sperm capacitation includes a cascade of biochemical changes that must occur before spermatozoa can effectively interact with an oocyte, as PKAdependent protein tyrosine phosphorylation, cholesterol efflux, actin polymerization, increases in $\left[\mathrm{Ca}^{2+}\right] \mathrm{i}$ and

[Keywords: Sperm; protein translation; capacitation; fertilization; mitochondrial ribosomes]

${ }^{1}$ Corresponding author.

E-MAIL breith@mail.biu.ac.il; FAX 972-3-5344766.

Article published online ahead of print. Article and publication date are at http://www.genesdev.org/cgi/doi/10.1101/gad.367606. changes in sperm motility (Breitbart 2003). Binding to the oocyte zona pellucida $(\mathrm{ZP})$ induces the sperm cell to undergo the acrosomal reaction and to penetrate the oocyte (Primakoff and Myles 2002).

We hypothesized that new proteins are synthesized in spermatozoa to (1) replace proteins that degrade in the delay before fertilization and (2) produce capacitationspecific proteins. The present study demonstrates for the first time that protein translation does occur in mammalian spermatozoa prior to fertilization.

\section{Results and Discussion}

Sperm incubated under capacitation conditions incorporate $\left[{ }^{35} \mathrm{~S}\right]$ Methionine (Met) $-\left[{ }^{35} \mathrm{~S}\right]$ Cysteine (Cys) into newly synthesized polypeptides (Fig. 1A). Novel protein translation was demonstrated in human, mouse, bovine, and rat sperm, indicating the widespread nature of this phenomenon. Labeled amino acid incorporation was completely blocked by the mitochondrial translation inhibitors D-chloramphenicol (CP) (Fig. 1A) tetracycline and gentamycin (Supplementary Fig. S1), but not by the cytoplasmic 80S ribosomal inhibitor cycloheximide (CH) (Fig. 1A), indicating that protein translation in sperm involves mitochondrial but not cytoplasmic ribosomes.

The incorporation was also completely inhibited by the mitochondrial uncoupler FCCP /carbonylcyanide ptrifluoromethoxyphenyl hydrazone) (Supplementary Fig. $\mathrm{S} 1 \mathrm{~b}, \mathrm{c})$, indicating the dependence of the protein translation on mitochondrial synthesized ATP and/or mitochondrial $\Delta \Psi$.

To visualize the cellular site of the nascent translated proteins within sperm cells, we used BODIPY-lysinetRNA $^{\text {Lys }}$ that labels newly made polypeptides in permeabilized capacitating spermatozoa in which the mitochondria are intact. High fluorescence was detected mainly in the sperm midpiece, and relatively low signal was detected in the principal part of the tail (Fig. 1B, panels 2,4). The labeling was inhibited in $98 \%$ of the cells by $\mathrm{CP}$ (Fig. 1B, panel 3), but not by $\mathrm{CH}$ (data not shown).

Both the ${ }^{35} \mathrm{~S}$-amino acid and BODIPY-lysine-tRNA ${ }^{\text {Lys }}$ labeling techniques revealed a plateau after $1 \mathrm{~h}$ of incubation under capacitation conditions (Fig. 1C; Supplementary Fig. S2), showing the consistency of the two techniques.

To identify specific proteins that are translated during sperm capacitation, the levels of sperm-related proteins were measured by Western blot (Supplementary Table S1). CP reduced the levels of 22 proteins including sperm-specific proteins. For example, CP treatment reduced the level of protein kinase C (PKC) (Breitbart and Naor 1999), angiotensin II type I receptor $\left(\mathrm{AT}_{1}-\mathrm{R}\right)$ (Gur et al. 1998), epidermal growth factor receptor (EGFR) (Lax et al. 1994), and progesterone receptor (PR) (Meizel and Turner 1991), which are involved in sperm capacitation, acrosome reaction, and fertilization. CP treatment also reduced the sperm-specific proteins CatSper (Ren et al. 2001), Na-K-ATPase $\alpha I V$ (Woo et al. 2000), the catalytic subunit of protein kinase A (PKA-Cs) (San Agustin and Witman 2001), and AKAP 110 (Vijayaraghavan et al. 1999). In addition, CP reduced cytochrome C, which is an intramitochondrial protein. On the other hand, CP did not reduce the expression of 4 of the 17 protein ki- 
A
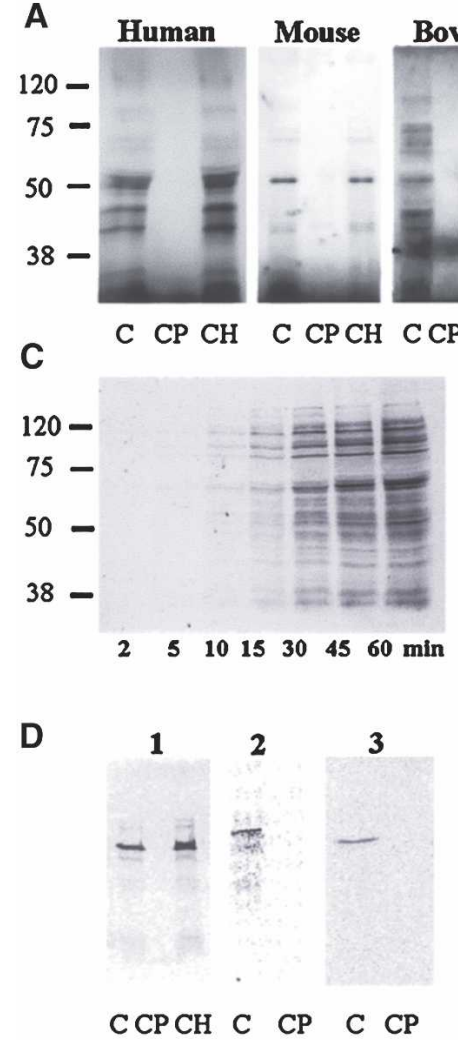

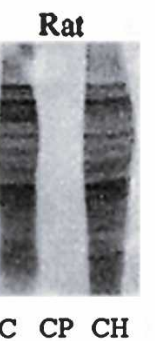

B
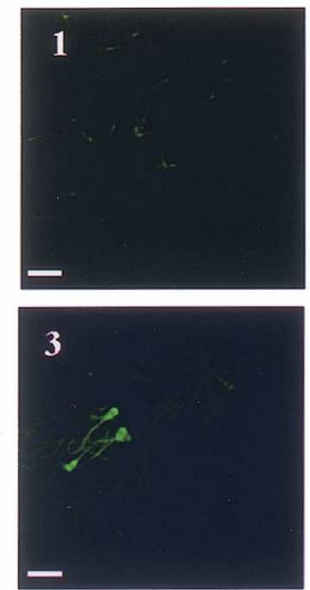

E

\section{1.}
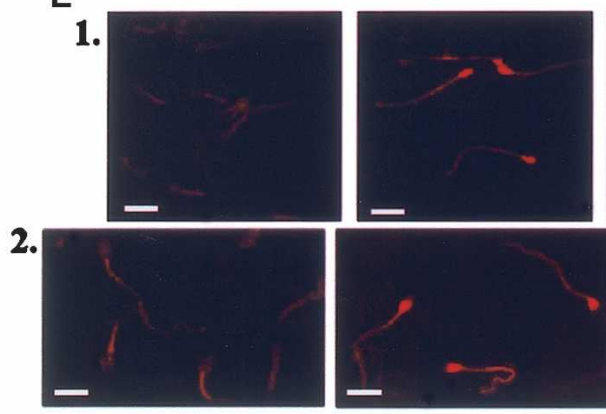

Oh

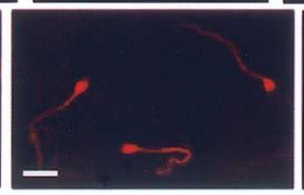

4h Control
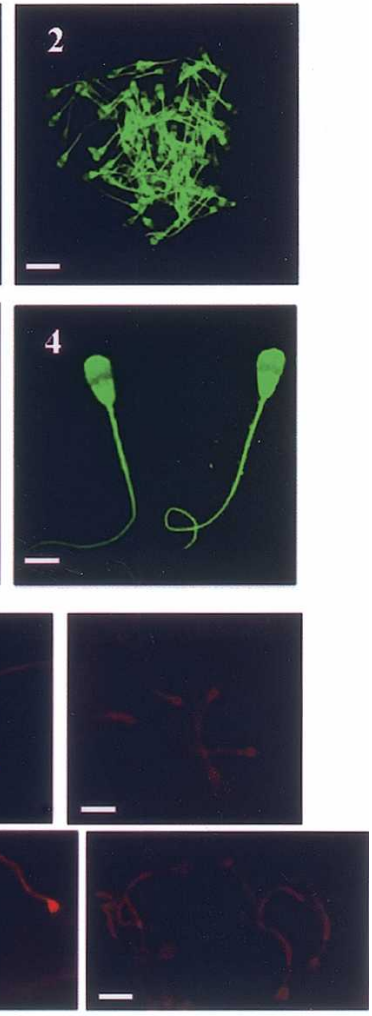

4h CP

Figure 1. Protein synthesis in spermatozoa. (A) Autoradiogram of an electrophoretic gel with $\left[{ }^{35} \mathrm{~S}\right] \mathrm{Met}-\left[{ }^{35} \mathrm{~S}\right]$ Cys-labeled polypeptides from human, bovine, mouse, and rat sperm incubated for 6, 4, 3, and $3 \mathrm{~h}$, respectively. Sperm were incubated under capacitation conditions with no additional treatment $(\mathrm{C})$ or after treatment with $\mathrm{CP}(0.1 \mathrm{mg} / \mathrm{mL})$ or $\mathrm{CH}(1 \mathrm{mg} / \mathrm{mL})$. (B) Fluorescence photograph of bovine sperm with BODIPYlysine-tRNA ${ }^{\text {Lys }}$-labeled polypeptides photographed at $0 \mathrm{~h}$ (panel 1), or after $1 \mathrm{~h}$ capacitation without (panels 2,4) or with (panel 3) CP treatment. Bar: panels 1-3, $40 \mu \mathrm{m}$; panel 4, $10 \mu \mathrm{m}$. (C) Time course of [ ${ }^{35} \mathrm{~S} \mid \mathrm{Met}-\left[{ }^{35} \mathrm{~S} \mid \mathrm{Cys}\right.$ incorporation into polypeptides in bovine sperm under capacitation conditions. (D) Immunoprecipitation of $\left[{ }^{35} \mathrm{~S}\right] \mathrm{Met}-\left[{ }^{35} \mathrm{~S}\right]$ Cys-labeled: angiotensin II type I receptor $\left(\mathrm{AT}_{1}-\mathrm{R}\right)($ lanes 1$)$, progesterone receptor (PR) (lanes 2), and PKC $\alpha$ after $4 \mathrm{~h}$ under capacitation conditions with no additional treatment (C) or after treatment with CP $(0.1 \mathrm{mg} / \mathrm{mL}) \mathrm{or} \mathrm{CH}(1$ $\mathrm{mg} / \mathrm{mL}$ ) (lanes 3). (E) Immunocytochemistry of $\mathrm{AT}_{1}-\mathrm{R}$ (row 1) and PR (row 2) in bovine sperm at $0 \mathrm{~h}$ and at $4 \mathrm{~h}$ of capacitation $\pm \mathrm{CP}(0.1 \mathrm{mg} / \mathrm{mL}$ ). Bar, $20 \mu \mathrm{m}$.

nases examined, indicating that those kinases are relatively stable during sperm capacitation (Supplementary Table S1). We assume that some of the degraded proteins must be replaced by newly synthesized proteins.

Identification of ${ }^{35} \mathrm{~S}$-amino acids labeled $\mathrm{AT}_{1}-\mathrm{R}, \mathrm{PR}$, and PKC $\alpha$ was performed by immunoprecipitation. The addition of CP to the cells completely blocked their synthesis while $\mathrm{CH}$ had no effect (Fig. 1D). Similarly, there was a significant increase in the amount of $\mathrm{AT}_{1}-\mathrm{R}$ and PR during capacitation as measured by immunocytochemistry, a phenomenon that was blocked by CP application (Fig. 1E).

It is likely that mRNA is present in sperm cells to serve as a template for the translation of new proteins. Indeed, RNA transcripts for the sperm-specific CatSper and CatSper II, Na-K ATPase $\alpha I V$, PKA-Cs, and AKAP 110 proteins were detected in sperm from several species, using RT-PCR (Fig. 2A).

Possible sources of mRNA in sperm might be newly transcribed mRNA molecules or long-lasting mRNA molecules transcribed during spermatogenesis. [ $\left.{ }^{35} \mathrm{~S}\right] \mathrm{Met}-$ $\left[{ }^{35} \mathrm{~S}\right]$ Cys incorporation into proteins was unaffected by the transcription inhibitor actinomycin D (Supplementary Fig. S1b,c), suggesting that the source of mRNA for protein translation is long-lasting mRNAs.
The localization of mRNAs and proteins at a specific cellular site may be an indication of the protein translation site. Thus, the cellular localization of bovine $\mathrm{AT}_{1}-\mathrm{R}$, mouse PKA-Cs, and mouse CatSper mRNA and proteins was determined. In situ hybridization of digoxigenin (DIG)-conjugated CatSper antisense PCR fragments with permeabilized sperm cells revealed high fluorescence in the sperm midpiece and head (Fig. 2B). This suggests that protein translation might occur in the midpiece mitochondria and/or in the head.

To further support this suggestion, specific mRNAs were localized at the organelle level using DIG-conjugated antisense visualized by electron microscopy. Bovine $\mathrm{AT}_{1}-\mathrm{R}$, mouse PKA-Cs, and mouse CatSper mRNAs were found predominantly inside the sperm mitochondria (Fig. 2C) as well as in the nucleus (data not shown).

Bovine $\mathrm{AT}_{1}-\mathrm{R}$, mouse PKA-Cs, and CatSper proteins were also localized at the cell organelle level using specific antibodies detected by secondary gold-conjugated antibody. All three proteins were localized inside the mitochondria (Fig. 2C), as well as in their active sites outside the mitochondria (data not shown). $\mathrm{AT}_{1}-\mathrm{R}$ protein was also localized to the sperm head (Supplementary Fig. S3).

The demonstration of the presence of activated ribo- 
A

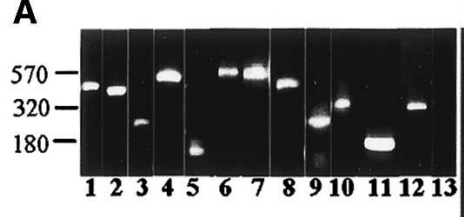

C

Bovine AT $1-R$ :

mRNA

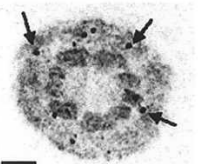

Mouse CatSper:
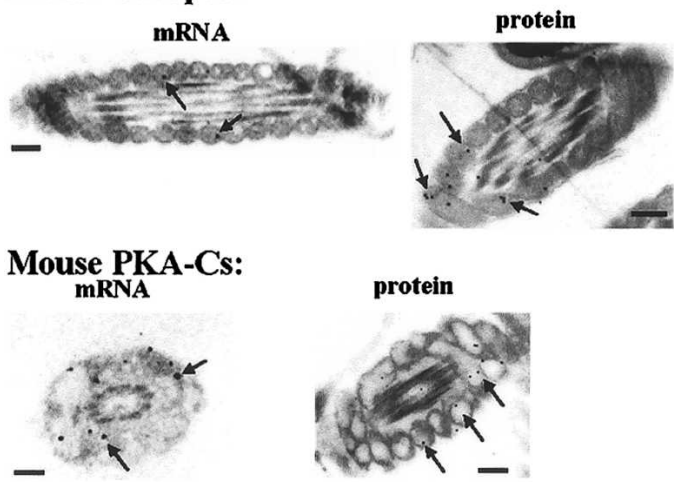

B
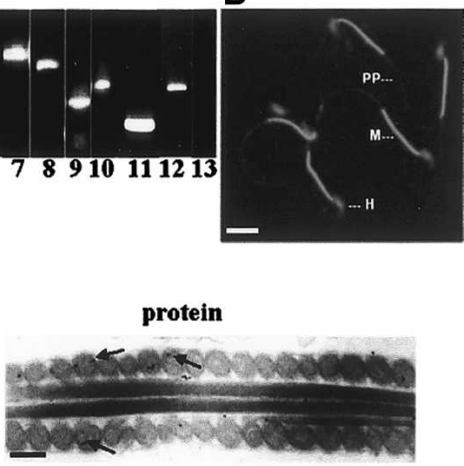

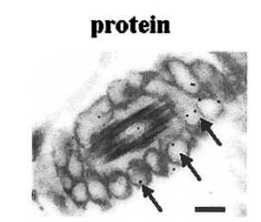

Figure 2. Identification and localization of mRNAs and proteins in sperm. (A) RT-PCR of sperm-related mRNA. Sperm RNA was purified and amplified by RT-PCR using specific primers (Supplementary Table S2). PCR products are mouse PKA-Cs (lane 1), bovine PKA-Cs (lane 2), human PKC $\alpha$ (lane 3), bovine AKAP 110 (lane 4), human PKC $\beta I$ (lane 5), mouse CatSper (lane 6), human CatSper (lane 7), mouse CatSper II (lane 8), human ATPase $\alpha 4$ (lane 9), rat ATPase $\alpha 4$ (lane 10), human $\mathrm{AT}_{1}-\mathrm{R}$ (lane 11), bovine $\mathrm{AT}_{1}-\mathrm{R}$ (lane 12), and control-PCR with mRNA but without RT (lane 13). (B) Immunostaining of CatSper mRNA in mouse sperm by in situ hybridization. The head $(\mathrm{H})$, midpiece $(\mathrm{M})$, and principal piece $(\mathrm{PP})$ regions of the sperm are indicated. (C) Immunogold localization of bovine AT1-R (top row), mouse Catsper (middle row), and mouse PKA-Cs (bottom row) mRNAs and proteins by electron microscopy. Cross-section is through the midpiece of bovine and mouse sperm, and the arrows indicate gold particles localized inside the mitochondria. Bar, 0.2 $\mu \mathrm{m}$.

somes in capacitating sperm cells would further support the contention of protein translation in sperm. Sperm ribosomes were analyzed using a sucrose gradient and RT-PCR. The configurations of mitochondrial (55S) and cytoplasmic (80S) ribosomes were evaluated. The $12 \mathrm{~S}$ rRNA, a component of the $28 \mathrm{~S}$ small subunit of the $55 \mathrm{~S}$ mitochondrial ribosome (Sharma et al. 2003), was found in all fractions (Fig. 3A). The presence of $12 \mathrm{~S}$ rRNA in the polysomal fractions indicates that the $55 \mathrm{~S}$ ribosomes are actively involved in sperm protein translation. On the other hand, the 18S rRNA, a component of the 40S small subunit of the 80S cytoplasmic ribosome, was identified only as subunits or monosomes (around fractions 2-8), however not in the polysomal fractions (Fig. $3 \mathrm{~B})$, indicating that $80 \mathrm{~S}$ ribosomes are present but not active in spermatozoa.

In addition, AKAP 110 mRNA was present in the poly-

somal fractions (Fig. 3C), indicating that this sperm-specific, nuclear-encoded protein is likely to be translated in sperm by $55 \mathrm{~S}$ mitoribosome. To our knowledge, this is the first indication for the translation of nuclear encoded mRNA on mitochondrial ribosomes. At this point it is not clear how the initiation of translation of the nuclear mRNA on the mitoribosome is operating. In bacteria, the initiation $\left(5^{\prime}\right)$ AUG is guided to its correct position by the Shine-Dalgarno sequence in the mRNA. In eukaryotes the initiation (5')AUG is located within the mRNA not by its proximity to a Shine-Dalgarno-like sequence but by a scan of the mRNA from the 5 ' end until the first AUG is encountered. A complex of initiation factors called eIF4F is probably involved in the scanning process. It seems that mitochondrial mRNA does not have the Shine-Dalgarno sequence (Denslow et al. 1989). This point will need further investigation in the future.

mRNAs and their translated proteins were localized both inside and outside of the mitochondria, supporting the notion that protein translation of nuclear-encoded proteins in sperm occurs either in the mitochondria and/ or by mitochondrial-type ribosomes located outside the mitochondria. These two possibilities raise a number of questions about how nuclear-encoded mRNAs are transported into the mitochondrion and how they are translated by mitochondrial ribosomes.

Experimental findings supporting the import of RNA into the mitochondria including tRNA in yeast, plants, and protozoans (Entelis et al. 2001) and 5S rRNA in mammalian cells (Doersen et al. 1985). On the other hand, experimental findings that mitochondrial-type ribosomes are present outside of the mitochondria in the germ plasm of Drosophila embryos (Amikura et al. 2001; Marc et al. 2002) and in a discrete region of egg cytoplasm in ascidian and sea urchin embryos (Ogawa et al.

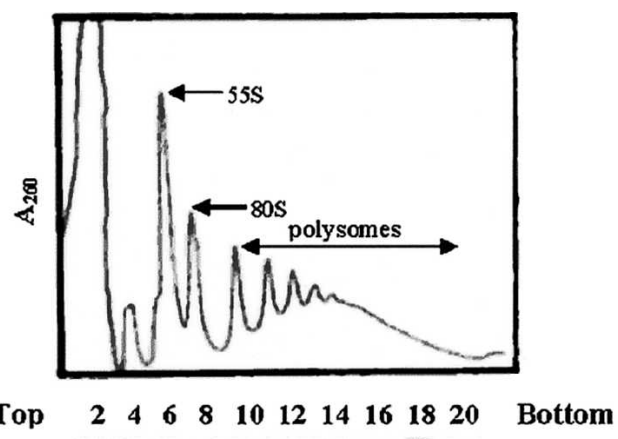

(a) $-\infty 0-\infty-\infty-\infty \mathrm{S}$ rRNA

(b)

(c)

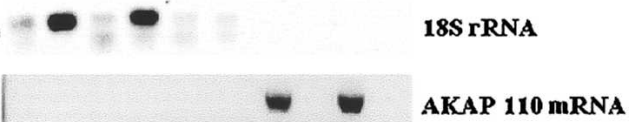

Figure 3. Identification of active sperm ribosomes. Sperm ribosomal fraction was allowed to sediment using sucrose gradient, then the optical density tracing at $260 \mathrm{~nm}$ was determined, 20 fractions were collected, and the absorbance measured at $260 \mathrm{~nm}$ in each fraction was measured again. RNA was isolated from each fraction and treated with DNase. All fractions were detected for the presence of rRNAs. 12S rRNA of the 55S mitochondrial ribosome $(a)$ and $18 \mathrm{~S}$ rRNA of the 80S cytoplasmic ribosomes $(b)$ were identified by RTPCR at the linear phase of the PCR. (c) mRNA of AKAP 110 was identified by RT-PCR. The S values were determined using standards for $55 \mathrm{~S}$ mitoribosomes and $80 \mathrm{~S}$ cytoplasmic ribosomes from HeLa cells. 
1999; Oka et al. 1999) support the possibility that atypical translation may occur in mitochondrial ribosomes outside of the mitochondria. Similarly, particles resembling ribosomes are associated with spermatid acrosomal membranes in spermatozoa (Mollenhauer and Morre 1978).

Additionally, 16S mitochondrial rRNA are localized in the nucleus of mouse spermatogenic cells and human spermatozoa (Villegas et al. 2002) indicating that these rRNAs may form ribosomes in the nucleus. Protein translation takes place in the nuclei of HeLa cells (Iborra et al. 2001) via 80S ribosomes, which raises the possibility that unexpected cellular loci may control atypical translation processes.

Thus, one possible explanation of the present findings is that protein translation occurs in the sperm nucleus via mitochondrial-type ribosomes that are sensitive to CP. Indeed, in situ hybridization assays demonstrated that $\mathrm{AT}_{1}-\mathrm{R}$ was localized to the sperm nucleus (Supplementary Fig. S3), suggesting that this protein may be translated by nuclear $55 \mathrm{~S}$ ribosomes or translocated to the nucleus after extranuclear translation.

The physiological importance of protein synthesis in sperm was evaluated by testing sperm motility, capacitation (actin polymerization and acrosome reaction) (Brener et al. 2003; Cohen et al. 2004), and in vitro fertilization.

All functional measures were reduced by CP treatment in a time-dependent manner (Fig. 4). A 6-h incubation with CP reduced sperm motility by $60 \%$, the acrosome reaction rate by $80 \%$, almost completely blocked actin polymerization $(90 \%)$, and inhibited in vitro fertilization by $45 \%$ (Fig. 4). The in vitro fertilization rate was reduced by $61 \%$ after $12 \mathrm{~h}$ of CP treatment. During treatment with $\mathrm{CP}$, the ongoing translation of a variety of proteins is blocked; however, the cell is still able to function using existing proteins until they are degraded. The functional inhibition by CP treatment was time-dependent, indicating that it may be related to the rate of protein degradation. It is likely that spermatozoa synthesize new proteins needed for capacitation and replace proteins that have degraded during the spermatozoa's substantial sojourn in the female genital tract before fertilization. As described in the introduction, previous works failed to undoubtedly prove that translation occurs in

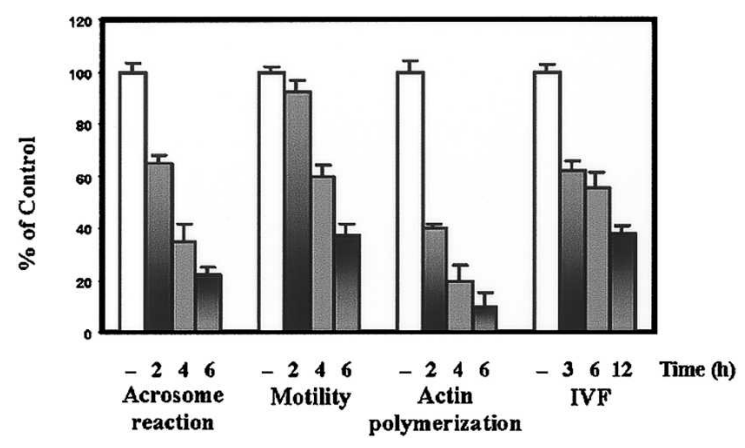

Figure 4. Inhibition of sperm functions by CP. Bovine sperm were incubated in capacitation medium for the specified times with (gray columns) or without (white column) $0.1 \mathrm{mg} / \mathrm{mL} \mathrm{CP}$. At the end of the incubation, sperm motility, actin polymerization, acrosome reaction, and in vitro fertilization rates were determined. Data are expressed as percentage of control \pm SD from four independent experiments. spermatozoa. In the 1970s, capacitation was not well defined; thus scientists failed to incubate cells under optimal conditions and to induce capacitation. Moreover, as of today, more accurate techniques, such as RT-PCR, have been developed, and thousands of mRNA species have been identified in sperm, indicating the optional use of these mRNAs for protein synthesis.

In summary, the data in the present study indicate that 55S mitochondrial ribosomes conduct nuclear-encoded protein translation during sperm capacitation. Protein translation is essential for sperm functions that contribute to fertilization, such as motility, actin polymerization, and the acrosome reaction. Thus, the ability of spermatozoa to synthesize proteins, including nuclear-encoded proteins, by the 55S ribosomal machinery is critical for the final maturation step leading to successful fertilization.

\section{Materials and methods}

In the methods below all chemicals were obtained from Sigma unless otherwise stated.

Sperm preparation and capacitation

Human semen was obtained from healthy donors. After liquefaction, the semen was loaded on a percoll gradient $(95 \%, 65 \%, 40 \%$, and $20 \%)$ and centrifuged for $30 \mathrm{~min}$ at $9000 \mathrm{rpm}$ at room temperature. The lower layer containing the sperm was collected and washed twice in HAM F-10, then spun again and incubated for "swim-up" for $30 \mathrm{~min}$ at $37^{\circ} \mathrm{C}$. The motile cells were collected without the pellet and resuspended in capacitation medium.

Ejaculated bovine semen was collected by artificial vagina. The semen was washed twice in buffer containing $110 \mathrm{mM} \mathrm{NaCl}, 5 \mathrm{mM} \mathrm{KCl}$, and 10 $\mathrm{mM}$ MOPS ( $\mathrm{pH}$ 7.4), and left for swim-up before the third wash, then resuspended in capacitation medium.

Sexually mature male mice (Balb/c) and rats (Sprague-Dawley) were sacrificed by $\mathrm{CO}_{2}$ asphyxiation. The pair of cauda epididymides and part of the vas-deferens were rapidly removed and minced in $0.5 \mathrm{~mL} \mathrm{HM}$ medium (modified Krebs-Ringer bicarbonate medium; Visconti et al. 1995). The sperm were released from the epididymal lumen for $10 \mathrm{~min}$ at $37^{\circ} \mathrm{C}$. The medium was carefully collected and the cells were washed twice at the same medium, and then left for swim-up for 20 min at $37^{\circ} \mathrm{C}$. The motile fraction was carefully collected and resuspended in capacitation medium.

Sperm from all sources were carefully separated from somatic cells or microorganisms by swim-up, and were checked for the absence of round and somatic cells by light microscopy. For bacterial contamination detection, samples of sperm suspension were smeared on Heart and Brain agar plates and left overnight at $37^{\circ} \mathrm{C}$ to verify the absence of microorganisms' colonies.

Sperm were capacitated by incubation in capacitation media that were supplemented with Penicillin (200 units/mL), cephalexin $(200 \mu \mathrm{g} / \mathrm{mL})$ (for penicillin-resistant microorganisms), and a mixture of amino acids. Human sperm $\left(30 \times 10^{6} / \mathrm{mL}\right)$ were incubated for $6 \mathrm{~h}$ at $37^{\circ} \mathrm{C}$ in HAM F-10 (Biological Industries) containing $0.5 \mathrm{mM} \mathrm{MgCl}, 15 \mathrm{mM}$ HEPES (pH 7.4), and $3 \mathrm{mg} / \mathrm{mL}$ HSA. Bovine sperm $\left(10^{8} / \mathrm{mL}\right)$ were incubated for $4 \mathrm{~h}$ at $39^{\circ} \mathrm{C}$ in m-TALP (modified Tyrode's medium) containing $100 \mathrm{mM} \mathrm{NaCl}, 3.1$ $\mathrm{mM} \mathrm{KCl}, 1.5 \mathrm{mM} \mathrm{MgCl}_{2}, 0.24 \mathrm{mM} \mathrm{KH}_{2} \mathrm{PO}_{4}, 25 \mathrm{mM} \mathrm{NaHCO}, 40 \mathrm{mM}$ HEPES, $0.1 \mathrm{mM}$ pyruvic acid, $21.6 \mathrm{mM}$ Na lactate, $10 \mathrm{mg} / \mathrm{mL}$ heparin, $0.2 \mathrm{M} \mathrm{CaCl}_{2}$, and $3 \mathrm{mg} / \mathrm{mL} \mathrm{BSA}$. Mouse or rat epididymal sperm $\left(10^{7} / \mathrm{mL}\right)$ were incubated for $3 \mathrm{~h}$ at $37^{\circ} \mathrm{C}$ in $\mathrm{HMB}$ (Visconti et al. 1995).

\section{Protein labeling by ${ }^{35}$ S/Met- ${ }^{35}$ S/Cys incorporation}

Sperm were incubated in capacitation media as follows: human sperm from healthy donors in HAM F-10 (Biological Industries) containing 0.5 $\mathrm{mM} \mathrm{MgCl} 2,15 \mathrm{mM}$ HEPES (pH 7.4), and $3 \mathrm{mg} / \mathrm{mL}$ HAS; bovine sperm in m-TALP (modified Tyrode's medium) (Parrish et al. 1989) containing 3 $\mathrm{mg} / \mathrm{mL} \mathrm{BSA}$ and mouse (Balb/c) and rat (Sprague-Dawley) epididymal sperm in HMB (Visconti et al. 1995). All media contained penicillin (200 units $/ \mathrm{mL}$ ), cephalexin $(200 \mu \mathrm{g} / \mathrm{mL}$ ) (for penicillin-resistant microorganisms) (Teva), a mixture of unlabeled amino acids, and $\left[{ }^{35} \mathrm{~S}\right] \mathrm{Met}-\left[{ }^{35} \mathrm{~S}\right] \mathrm{Cys}$ 
$(30 \mu \mathrm{Ci} / \mathrm{mL}) \mid{ }^{35} \mathrm{~S}-{ }^{35} \mathrm{~S}$-protein labeling mix; NEN). Sperm proteins were separated on SDS-PAGE and exposed to film for 2 wk.

Protein labeling by lysyl-transfer RNA tagged with BODIPY

Partially permeabilized bovine sperm were incubated with FluoroTect Green $_{\text {Lys }}$ [4,4-difluoro-5,7-dimethyl-4-bora-3a,4a-diaza-s-indacene-3-propanoyl-lysyl-tRNA Lys $_{\text {S }}$ (Promega). Aliquots were spread on coverslips, allowed to dry in the dark, and examined using a confocal microscope (MRC1024, Bio-Rad). The fluorescent intensity was quantitatively analyzed using "Image J" (NIH Image) software.

Detection methods for specific proteins of interest

For immunoprecipitation, sperm were capacitated for $4 \mathrm{~h}$ in the presence of $\left[{ }^{35} \mathrm{~S}\right]$ Met- $\left[{ }^{35} \mathrm{~S}\right] \mathrm{Cys}$-labeled amino acids, lysed, and immunoprecipitated with anti-AT ${ }_{1}-\mathrm{R}$, anti-PKC $\alpha$, or anti-PR antibodies (Santa Cruz Biotechnology).

For immunostaining, capacitated and uncapacitated sperm were incubated with anti- $\mathrm{AT}_{1}-\mathrm{R}$ or anti-PR followed by rhodamine-conjugated anti-rabbit secondary antibody.

For immuno-electron microscopy, anti-CatSper (a gift from D.E. Clapham, Howard Hughes Medical Institute, Children's Hospital, Boston, MA), anti-PKA-Cs (a gift from G.B. Witman, Department of Cell Biology, University of Massachussetts Medical School, Worcester, MA), or anti- $\mathrm{AT}_{1}-\mathrm{R}$ antibodies were added to $100-\AA \AA$ sections of embedded sperm cells and then incubated with $15 \mathrm{~nm}$ gold-conjugated secondary antibody (Zymed). Control experiments produced only background level signals.

mRNA detection methods

Total RNA was extracted from spermatozoa by RNAqueous-4PCR kit (Ambion). RT-PCR was performed with specific primers (see Supplementary Table S2). The sequences were cut with the appropriate restriction enzyme to verify the expected sequence.

mRNA localization of CatSper was detected in permeabilized sperm by hybridization with a DIG-labeled DNA fragment (see sequence in Supplementary Table S2) and anti-DIG rhodamine-conjugated antibody according to the manufacturer's instructions (Roche Applied Science).

Immunogold localization of mRNAs was performed on sperm sections using DIG-labeled antisenses. After hybridization, the grids were probed with 0.8-nm gold-labeled anti-DIG antibody and enhanced with silver at a ratio of 1:1 (silver:gold) for 4 min (Amersham). Controls for the specificity of the hybridization, including hybridization with antisense to transcripts not found in sperm (DIG-labeled enhanced green fluorescent protein [EGFP] and DIG-labeled SL, which represent splice leader subunit in Trypanosome mRNAs), secondary antibody without antisense, and prehybridization treatment with RNase. Control experiments produced only background level signals.

Analysis of ribosomes profile

Ejaculated bovine sperm cells were incubated in capacitation medium for $1 \mathrm{~h}$, then the cells were lysed in buffer A $\left(100 \mathrm{mM} \mathrm{NH}_{4} \mathrm{Cl}, 10 \mathrm{mM} \mathrm{MgCl}_{2}\right.$, $20 \mathrm{mM}$ Tris-Cl at $\mathrm{pH} 7.5$ ), containing $150 \mathrm{mM} \mathrm{KCl}, 0.1 \%$ SDS, $1.6 \%$ Triton, and proteases inhibitors. Cell debris were pelleted, and the lysate containing ribosomes was layered on continuous $10 \%-30 \%(\mathrm{w} / \mathrm{v})$ sucrose gradient in buffer A containing $150 \mathrm{mM} \mathrm{KCl}$ and centrifuged at 35,000 $\mathrm{rpm}$ for $3 \mathrm{~h}$ at $4^{\circ} \mathrm{C}$. Twenty fractions were collected and measured at $\mathrm{A}_{260}$ for total RNA. The RNA was extracted by ethanol/sodium-acetate and purified by RNaquose-4-PCR and DNase treatment. rRNAs and mRNA were identified by RT-PCR.

Sperm functional measurements

Sperm analyzed by functional assays: Motility was assessed by a "Sperm Motility Analyzer" (Bartoov et al. 1991), actin polymerization, and acrosome reaction using FITC-phalloidin and pissum-sativum-aglutinin staining, respectively (Mendoza et al. 1992), and in vitro fertilization with BALB-C mice by standard protocol (Eppig et al. 1996).

\section{Acknowledgments}

We gratefully acknowledge G.B. Witman and J.T. San Agustin for antiPKA-Cs, D.E. Clapham for the anti-CatSper, and D. Carr for anti AKAP
110 antibodies. This research was supported by the Israeli Science Foundation, funded by the Academy of Sciences and Humanities to H.B.

\section{References}

Alcivar, A.A., Hake, L.E., Millette, C.F., Trasler, J.M., and Hecht, N.B. 1989. Mitochondrial gene expression in male germ cells of the mouse. Dev. Biol. 135: 263-271.

Amikura, R., Kashikawa, M., Nakamura, A., and Kobayashi, S. 2001. Presence of mitochondria-type ribosomes outside mitochondria in germ plasm of Drosophila embryos. Proc. Natl. Acad. Sci. 98: 91339138.

Bartoov, B., Ben-Barak, J., Mayevsky, A., Sneider, M.Y.L., and Lightman, A. 1991. Sperm motility index: A new parameter for human sperm evaluation. Fertil. Steril. 56: 108-112.

Bragg, P.W. and Handel, M.A. 1979. Protein synthesis in mouse spermatozoa. Biol. Reprod. 20: 333-337.

Breitbart, H. 2003. Signaling pathways in sperm capacitation and acrosome reaction. Cell. Mol. Biol. 49: 321-327.

Breitbart, H. and Naor, Z. 1999. Protein kinases in mammalian sperm capacitation and the acrosome reaction. Rev. Reprod. 4: 151-159.

Brener, E., Rubinstein, S., Cohen, G., Shternall, K., Rivlin, J., and Breitbart, H. 2003. Remodeling of the actin cytoskeleton during mammalian sperm capacitation and acrosome reaction. Biol. Reprod. 68: 837845.

Cohen, G., Rubinstein, S., Gur, Y., and Breitbart, H. 2004. Crosstalk between protein kinase $\mathrm{A}$ and $\mathrm{C}$ regulates phospholipase $\mathrm{D}$ and $\mathrm{F}$ actin formation during sperm capacitation. Dev. Biol. 267: 230-241.

Denslow, N.D., Michaels, G.S., Montoya, J., Attardi, G., and O'Brien, T.W. 1989. Mechanism of mRNA binding to bovine mitochondrial ribosomes. J. Biol. Chem. 264: 8328-8338.

Doersen, C.J., Guerrier-Takada, C., Altman, S., and Attardi, G. 1985. Characterization of an RNase P activity from HeLa cell mitochondria. Comparison with the cytosol RNase P activity. J. Biol. Chem. 260: $5942-5949$.

Entelis, N.S., Kolesnikova, O.A., Martin, R.P., and Tarassov, I.A. 2001 RNA delivery into mitochondria. Adv. Drug Deliv. Rev. 49: 199-215.

Eppig, J.J., O'Brien, M., and Wigglesworth, K. 1996. Mammalian oocyte growth and development in vitro. Mol. Reprod. Dev. 44: 260-273.

Gur, Y., Breitbart, H., Lax, Y., Rubinstein, S., and Zamir, N. 1998. Angiotensin II induces acrosomal exocytosis in bovine spermatozoa. Am. J. Physiol. 275: E87-E93.

Hecht, N.B. and Williams, J.L. 1978. Synthesis of RNA by separated heads and tails from bovine spermatozoa. Biol. Reprod. 19: 573-579.

Iborra, F.J., Jackson, D.A., and Cook, P.R. 2001. Coupled transcription and translation within nuclei of mammalian cells. Science 293: 1139-1142.

Lax, Y., Rubinstein, S., and Breitbart, H. 1994. Epidermal growth factor induces acrosomal exocytosis in bovine sperm. FEBS Lett. 339: 234 238.

Marc, P., Margeot, A., Devaux, F., Blugeon, C., Corral-Debrinski, M., and Jacq, C. 2002. Genome-wide analysis of mRNAs targeted to yeast mitochondria. EMBO Rep. 3: 159-164.

Meizel, S. and Turner, K.O. 1991. Progesterone acts at the plasma membrane of human sperm. Mol. Cell. Endocrinol. 77: R1-R5.

Mendoza, C., Carreras, A., Moos, J., and Tesarik, J. 1992. Distinction between true acrosome reaction and degenerative acrosome loss by a one-step staining method using Pisum sativum agglutinin. J. Reprod. Fertil. 95: 755-763.

Miller, D., Briggs, D., Snowden, H., Hamlington, J., Rollinson, S., Lilford, R., and Krawetz, S.A. 1999. A complex population of RNAs exists in human ejaculate spermatozoa: Implications for understanding molecular aspects of spermiogenesis. Gene 237: 385-392.

Mollenhauer, H.H. and Morre, D.J. 1978. Polyribosomes associated with forming acrosome membranes in guinea pig spermatids. Science 200: 85-86.

Ogawa, M., Amikura, R., Akasaka, K., Kinoshita, T., Kobayashi, S., and Shimada, H. 1999. Asymmetrical distribution of mitochondrial rRNA into small micromeres of sea urchin embryos. Zoo. Sci. 16: 445-451.

Oka, T., Amikura, R., Kobayashi, S., Yamamoto, H., and Nishida, H. 1999. Localization of mitochondrial large ribosomal RNA in the myoplasm of the early ascidian embryo. Dev. Growth Differ. 41: 1-8. 


\section{Gur and Breitbart}

Ostermeier, G.C., Dix, D.J., Miller, D., Khatri, P., and Krawetz, S.A. 2002. Spermatozoal RNA profiles of normal fertile men. Lancet $\mathbf{3 6 0}$ : 772-777.

Parrish, J.J., Susko-Parrish, J.L., and First, N.L. 1989. Capacitation of bovine sperm by heparin: Inhibitory effect of glucose and role of intracellular pH. Biol. Reprod. 41: 683-699.

Premkumar, E. and Bhargava, P.M. 1972. Transcription and translation in bovine spermatozoa. Nat. New Biol. 240: 139-143.

Primakoff, P. and Myles, D.G. 2002. Penetration, adhesion, and fusion in mammalian sperm-egg interaction. Science 296: 2183-2185.

Ren, D., Navarro, B., Perez, G., Jackson, A.C., Hsu, S., Shi, Q., Tilly, J.L., and Clapham, D.E. 2001. A sperm ion channel required for sperm motility and male fertility. Nature 413: 603-609.

San Agustin, J.T. and Witman, G.B. 2001. Differential expression of the $\mathrm{C}(\mathrm{s})$ and $\mathrm{C} \alpha \mathrm{l}$ isoforms of the catalytic subunit of cyclic $3^{\prime}, 5^{\prime}$-adenosine monophosphate-dependent protein kinase testicular cells. Biol. Reprod. 65: 151-164.

Sharma, M.R., Koc, E.C., Datta, P.P., Booth, T.M., Spremulli, L.L., and Agrawal, R.K. 2003. Structure of the mammalian mitochondrial ribosome reveals an expanded functional role for its component proteins. Cell 115: 97-108.

Suarez, S.S. 2002. Formation of a reservoir of sperm in the oviduct. Reprod. Domest. Anim. 37: 140-143.

Vijayaraghavan, S., Liberty, G.A., Mohan, J., Winfrey, V.P., Olson, G.E., and Carr, D.W. 1999. Isolation and molecular characterization of AKAP110, a novel, sperm-specific protein kinase A-anchoring protein. Mol. Endocrinol. 13: 705-717.

Villegas, J., Araya, P., Bustos-Obregon, E., and Burzio, L.O. 2002. Localization of the $16 \mathrm{~S}$ mitochondrial rRNA in the nucleus of mammalian spermatogenic cells. Mol. Hum. Reprod. 8: 977-983.

Visconti, P.E., Moore, G.D., Bailey, J.L., Laclerc, P., Connors, S.A., Pan, D., Olds-Clarke, P., and Kopf, G.-S. 1995. Capacitation in mouse spermatozoa. II. Protein tyrosine phosphorylation and capacitation are regulated by a cAMP-dependent pathway. Development 121: $1139-1150$

Woo, A.L., James, P.F., and Lingrel, J.B. 2000. Sperm motility is dependent on a unique isoform of the Na,K-ATPase. J. Biol. Chem. 275: 20693-20699.

Wykes, S.M., Visscher, D.W., and Krawetz, S.A. 1997. Haploid transcripts persist in mature human spermatozoa. Mol. Hum. Reprod. 3: 15-19. 


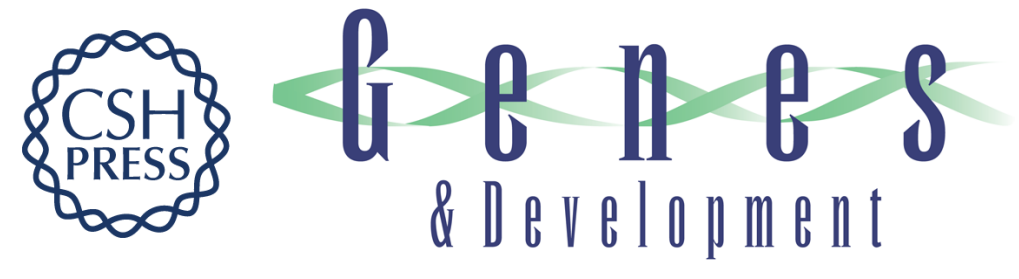

\section{Mammalian sperm translate nuclear-encoded proteins by mitochondrial-type ribosomes}

Yael Gur and Haim Breitbart

Genes Dev. 2006, 20:

Access the most recent version at doi:10.1101/gad.367606

\section{Supplemental http://genesdev.cshlp.org/content/suppl/2006/02/01/gad.367606.DC1 Material}

References This article cites 36 articles, 11 of which can be accessed free at: http://genesdev.cshlp.org/content/20/4/411.full.html\#ref-list-1

\section{License}

Email Alerting

Receive free email alerts when new articles cite this article - sign up in the box at the top Service right corner of the article or click here.

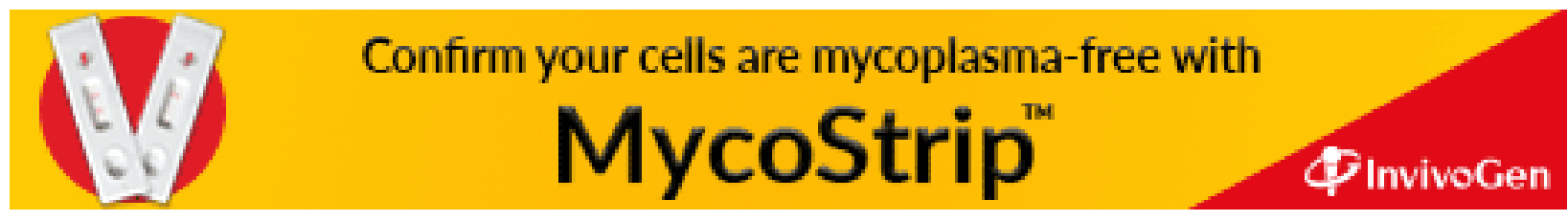

